\section{Porcine intestinal mast cells. Evaluation of different fixatives for histochemical staining techniques considering tissue shrinkage}

J. Rieger, ${ }^{1}$ S. Twardziok, ${ }^{2}$ H. Huenigen, ${ }^{1}$ R.M. Hirschberg, ${ }^{1}$ J. PlendI ${ }^{1}$

'Department of Veterinary Medicine, Institute for Veterinary Anatomy, Freie Universität Berlin

2Molecular Biology and Biolnformatics Institute, Charité - Universitätsmedizin Berlin, Germany

\section{Abstract}

Staining of mast cells (MCs), including porcine ones, is critically dependent upon the fixation and staining technique. In the pig, mucosal and submucosal MCs do not stain or stain only faintly after formalin fixation. Some fixation methods are particularly recommended for MC staining, for example the fixation with Carnoy or lead salts. Zinc salt fixation (ZSF) has been reported to work excellently for the preservation of fixation-sensitive antigens. The aim of this study was to establish a reliable histological method for counting of MCs in the porcine intestinum. For this purpose, different tissue fixation and staining methods that also allow potential subsequent immunohistochemical investigations were evaluated in the porcine mucosa, as well as submucosa of small and large intestine. Tissues were fixed in Carnoy, lead acetate, lead nitrate, Zamboni and ZSF and stained subsequently with either polychromatic methylene blue, alcian blue or toluidine blue. For the first time our study reveals that ZSF, a heavy metal fixative, preserves metachromatic staining of porcine MCs. Zamboni fixation was not suitable for histochemical visualization of MCs in the pig intestine. All other tested fixatives were suitable. Alcian blue and toluidine blue co-stained intestinal goblet cells which made a prima facie identification of MCs difficult. The polychromatic methylene blue proved to be the optimal staining. In order to compare MC counting results of the different fixation methods, tissue shrinkage was taken into account. As even the same fixation caused shrinkagedifferences between tissue from small and large intestine, different factors for each single fixation and intestinal localization had to be calculated. Tissue shrinkage varied between $19 \%$ and $57 \%$, the highest tissue shrinkage was found after fixation with ZSF in the large intestine, the lowest one in the small intestine after lead acetate fixation. Our study emphasizes that MC counting results from data using different fixation techniques can only be compared if the respective studyimmanent shrinkage factor has been determined and quantification results are adjusted accordingly.

\section{Introduction}

Being strategically positioned at epithelial barriers, the mast cell (MC) takes on an essential role in intestinal mucosal surveillance. ${ }^{1}$ MCs are well known for their role in allergy. Their ability to instantly degranulate and thus release soluble mediators from intracellular stores has been shown to be crucial for an optimal immune response. ${ }^{2}$ Increasingly MCs become recognized as an important cell type mediating stress-related intestinal disorders, ${ }^{1}$ but despite impressive progress, there are large gaps in our understanding of their phenotypic heterogeneity, of regulatory mechanisms involved and the functional significance. ${ }^{3}$ Only recently it was revealed that immunological responses to probiotic bacteria may be MC mediated. ${ }^{4}$ Probiotics as a dietary additive are claimed to improve the general health status of pigs, to reduce mortality and increase productivity rates, and are therefore in the focus of intense current research (e.g. recently reviewed in Cho et al. ${ }^{5}$ ), for example within a collaborative research center on intestinal microbiota-host interaction for which our laboratory provides a morphological profiling platform. The pig is also an important model for human intestinal physiology and pathology. ${ }^{6}$ In this frame careful qualitative and precise quantitative investigations including subsequent histochemistry of MCs in the porcine intestine are necessary. Although histomorphological visualization, staining and counting of cells often is considered to be a trivial task, this is not true for MCs. One reason for this is that MCs represent a heterogeneous population. This heterogeneity, according to Moon et al., can be differentiated on the basis of their location, histochemical staining properties, their content of proteases [mostly determined by immunohistochemistry (IHC)], and reactivity to selected secretagogues and antiallergic drugs. ${ }^{3}$ Initial research in the field of MC heterogeneity, including effects of fixation and staining, was done by Lennart Enerbäck. He described prominent differences for MCs concerning fixation sensitivity, morphology, membrane stability, granular content and dye binding properties between MCs situated in mucosal tissues and MCs found elsewhere, e.g. in the skin. ${ }^{7-10}$ In pigs, mucosal-type MCs and connective tissue-type MCs have like-
Correspondence: Juliane Rieger/Johanna Plendl, Department of Veterinary Medicine, Institute for Veterinary Anatomy, Freie Universität Berlin, Koserstraße 20, D-14195 Berlin, Germany. Tel. +49.30 .83853482 - Fax: +49.30 .83853480 . E-mail: juliane.rieger@fu-berlin.de johanna.plendl@fu-berlin.de

Key words: mast cell, swine, fixation, tissue shrinkage factor.

Acknowledgments: this study was supported by the German Research Foundation (DFG) through the Collaborative Research Centre 852 (Grant no. SFB852/1, www.sfb852.de).

The authors wish to acknowledge the role in collection of samples, and particularly their excellent technical assistance and expertise, of Barbara Drewes, Tania Fuhrmann-Selter and Karin Briest-Forch (Institute for Veterinary Anatomy, Freie Universität Berlin, Germany).

Contributions: JR, design, critical literature review, data collection, analysis and interpretation, draft of manuscript, final approval; ST, design, data collection, statistical data analysis and interpretation, final approval; HH, design, data analysis and interpretation, critical review, final approval; RMH, critical literature review, data interpretation, draft of manuscript, critical review, final approval; JP, design, data analysis and interpretation, draft of manuscript, critical review, final approval.

Conflict of interests: the authors declare that there is no conflict of interest that could be perceived as prejudicing the impartiality of the research reported.

Received for publication: 21 February 2013. Accepted for publication: 17 June 2013.

This work is licensed under a Creative Commons Attribution NonCommercial 3.0 License (CC BYNC 3.0).

(C) Copyright J. Rieger et al., 2013

Licensee PAGEPress, Italy

European Journal of Histochemistry 2013; 57:e21 doi:10.4081/ejh.2013.e21

wise been described due to histochemical properties. ${ }^{11}$ However, it is postulated that heterogeneity of MCs in tissues is much more diverse than merely two polarized phenotypes and is probably dynamically changing in accordance with micro-environmental conditions. ${ }^{3}$

For clinical diagnosis and in research studies, various methods are used to stain MCs; in particular, metachromatic stains are frequently employed. ${ }^{12-14}$ Several studies have shown that staining patterns of MCs, including the porcine ones, are critically dependent on the respective fixation technique employed. ${ }^{11,15-17}$ Apparently, the detection of MCs in formalin fixed specimens is dependent on the species 
and the localization. ${ }^{16,18-21}$ In the pig, mucosal and submucosal MCs did not stain or stained only faintly after formalin fixation ${ }^{11,17}$ and a similar phenomenon of loss of metachromatic staining of mucosal MCs is seen in rats and humans. ${ }^{15,22}$ There are some fixation methods that are particularly recommended for MC staining, for example the fixation with Carnoy or lead salts. ${ }^{15,16}$ One draw-back in characterisation of MCs by their histochemical as well as their IHC properties is that both techniques usually require different fixation techniques for optimal results, because fixatives conventionally employed for MC histochemistry do not allow optimal antigen preservation. ${ }^{16}$ For example, in a study on intestinal morphology and mucosal immunity of piglets, Che et al. used Bouin's fixative for histochemical analysis including MC counts, and cryo-fixation for IHC analysis of immune cells. ${ }^{23}$ Similarly, a study characterizing the intestinal mucosal immune cells of healthy young pigs used cryopreservation for RNAanalysis and Carnoy fixation for histochemical MC counting. ${ }^{24}$ Shetye et al. compared the immunohistochemical reactivity of various leukocyte antigens in frozen and paraffinembedded tissues of rats, fixed in various fixatives. Antigen reactivity after fixation in Carnoy, 4\% neutral buffered formalin and a mercury-based fixative (B-5) was not well preserved. ${ }^{25}$ Similarly, the immunoreactivity of an antibody to ferritin was totally destroyed by Carnoy's fixative. ${ }^{26}$ Of special interest is that Carnoy reduced the number of chymasepositive MCs in immunocytochemical staining of umbilical-cord-blood-derived human cultured MCs. ${ }^{27}$ In contrast to this, Zamboni's fixative has been reported to be excellent for immunolabelling of MCs in the rat. ${ }^{28}$ Another fixative, reported to be very effective for tissue preservation in different species and cell types, is zinc salt fixation (ZSF). It has been described to be clearly superior to formaldehyde, yielding results equal to cryopreservation; ${ }^{29,30}$ still, to the best of our knowledge, it has never been used on MCs, let alone porcine ones.

In the light of the heterogeneous results on MC visualization published for different species, tissues and organs following the use of various fixation and staining methods, the aim of this study was to establish a reliable histological method for counting of MCs in the porcine intestinum. For this purpose different tissue fixation and staining methods that also allowed potential subsequent immunohistochemical investigations of MCs in the porcine intestine were evaluated. Tissues were fixed in Carnoy, lead acetate, lead nitrate, Zamboni's fixative and zinc salt. Stainings used included polychromatic methylene blue, alcian blue and toluidine blue. In order to compare MC counting results between the different fixation methods, tissue shrinkage was taken into account.

\section{Materials and Methods}

\section{Sampling and tissues}

Samples were taken in the course of a feeding trial, approved by the local state office of health and social affairs affairs, Landesamt, Berlin (LaGeSo Reg. Nr. 0347/09). National guidelines for the care and use of laboratory animals were followed. Twenty 39 - to 55-day-old conventionally kept German Landrace piglets were sedated with $20 \mathrm{mg} / \mathrm{kg}$ body weight (BW) of ketamine hydrochloride (Ursotamin ${ }^{\circledR}, \quad$ Serumwerk Bernburg AG, Germany) and $2 \mathrm{mg} / \mathrm{kg}$ BW azaperone (Stresnil ${ }^{\circledR}$, Jansen-Cilag, Neuss, Germany) and then euthanized with an intracardial injection of $10 \mathrm{mg} / \mathrm{kg}$ BW tetracaine hydrochloride, mebezonium iodide and embutramide $\left(\mathrm{T} 61^{\circledR}\right.$, Intervet, Unterschleißheim, Germany). Samples of mid jejunum and colon ascendens were collected from all animals and used for MC quantification. Samples of six piglets were additionally used for the determination of the shrinkage factor (see below).

\section{Tissue processing}

The samples were rinsed in ice-cooled Ringer solution, cut open on the mesenterial side and then trimmed to approx. $2 \times 1 \mathrm{~cm}$ small squares, pinned loosely without stretching mucosal-side up on cork pieces and immediately fixed in the appropriate fixation solutions (Table 1).

Table 1. Standardized fixation procedures employed in this study, specifically adapted for the target tissue after fixation protocols indicated in the respective literature source.

\begin{tabular}{|c|c|c|c|}
\hline Fixation & Ingredients for 100 mL & Fixation time and temperature & Notes \\
\hline Carnoy ${ }^{31,32}$ & $\begin{array}{l}60 \mathrm{~mL} \text { ethanol, } \\
30 \mathrm{~mL} \text { chloroform, } \\
10 \mathrm{~mL} \text { glacial acetic acid }\end{array}$ & $\begin{array}{l}5-22 \mathrm{~h} \\
4^{\circ} \mathrm{C}\end{array}$ & $\begin{array}{l}\text { Dehydration starts with } 100 \% \text { ethanol - } \\
\text { solution freshly prepared before use }\end{array}$ \\
\hline Lead acetate ${ }^{33,34}$ & $\begin{array}{l}4 \mathrm{~g} \text { lead acetate } \times 3 \mathrm{H}_{2} \mathrm{O} \text { dissolved } \\
\text { in bidistilled water ad } 49 \mathrm{~mL}, \\
40 \mathrm{~mL} \text { ethanol, } \\
10 \mathrm{~mL} 37 \% \text { formalin, } \\
1 \mathrm{~mL} \text { glacial acetic acid }\end{array}$ & $\begin{array}{l}26 \mathrm{~h} \\
\text { room temperature }\end{array}$ & Dehydration starts with $70 \%$ ethanol \\
\hline Lead nitrate ${ }^{35,36}$ & $\begin{array}{l}8 \mathrm{~g} \text { lead nitrate dissolved in } \\
19 \mathrm{~mL} \text { bidistilled water, } \\
80 \mathrm{~mL} \text { ethanol, } \\
1 \mathrm{~mL} 37 \% \text { formalin }\end{array}$ & $\begin{array}{l}26 \mathrm{~h} \\
\text { room temperature }\end{array}$ & Dehydration starts with $80 \%$ ethanol \\
\hline Zamboni $^{31,37,38}$ & $\begin{array}{l}2 \mathrm{~g} \text { paraformaldehyde dissolved } \\
\text { in } 40 \mathrm{~mL} \text { bidistilled water, } \\
15 \mathrm{~mL} \text { picric acid } \\
\text { (saturated aqueous solution), } \\
42.5 \mathrm{~mL} \text { PBS (doubly concentrated), } \\
\text { bidistilled water ad } 100 \mathrm{~mL}\end{array}$ & $\begin{array}{l}26 \mathrm{~h} \\
4^{\circ} \mathrm{C}\end{array}$ & $\begin{array}{l}\text { Fixation is followed by } \\
\text { thorough rinsing in cold PBS }\left(4^{\circ} \mathrm{C}\right)\end{array}$ \\
\hline Zinc salt fixation ${ }^{39}$ & $\begin{array}{l}0.05 \mathrm{~g} \text { calcium acetate } \\
0.5 \mathrm{~g} \text { zinc acetate } \\
0.5 \mathrm{~g} \text { zinc chloride, } \\
1.2 \mathrm{~g} 0.1 \mathrm{M} \text { tris buffer, } \\
\text { bidistilled water ad } 100 \mathrm{~mL}\end{array}$ & $\begin{array}{l}26 \mathrm{~h} \\
4^{\circ} \mathrm{C} \text { or room temperature }\end{array}$ & Dehydration starts with $70 \%$ ethanol \\
\hline
\end{tabular}


Fixed tissues were dehydrated in graded series of ethanol, embedded in paraffin, cut to $5 \mu \mathrm{m}$ thin sections, put on slides, de-waxed in xylene, rehydrated and stained according to the specific staining protocols. All tissue processing steps were carried out by the same experienced staff according to standardized protocols.

\section{Histochemical staining}

Polychromatic methylene blue modified according to Unna: ${ }^{40}$

- Deparaffinization and hydration to distilled water

- $1 \%$ polychromatic methylene blue in distilled water - 10 min (Methylenblau -
Polychromes - Unna, Waldeck GmbH \& Co., Division Chroma, Muenster, Germany)

- Rinse subsequently in distilled water, tap water, distilled water

Differentiation in glycerine-ether (1:4 with distilled water) (Glycerinethermischung Unna, WALDECK GmbH \& Co Division Chroma, Muenster, Germany)
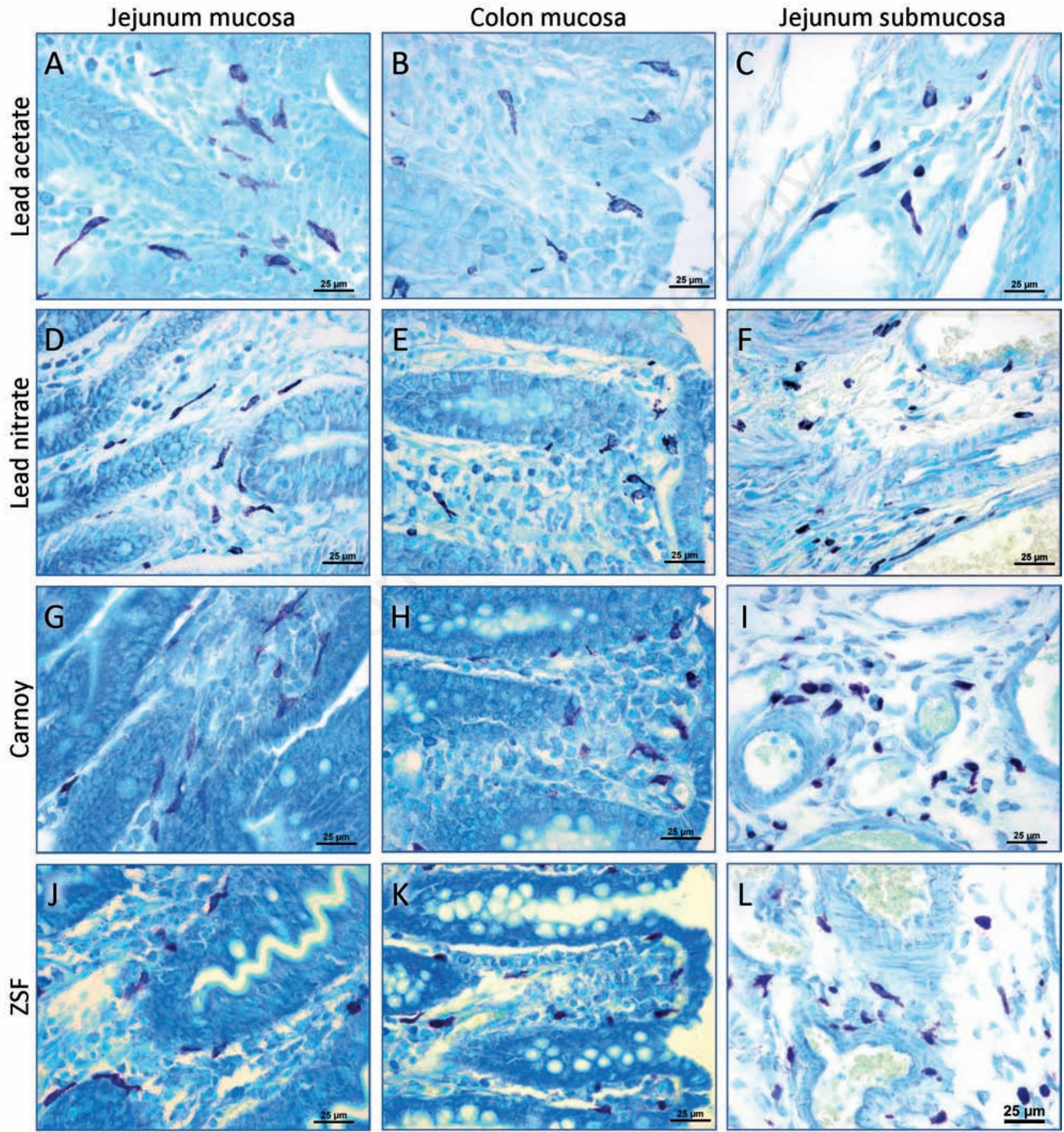

Figure 1. Histochemical demonstration of mast cells. A, B, C) Staining of jejunal and colonic tissue with polychromatic methylene blue after fixation in lead acetate. D, E, F) Fixation in lead nitrate. G, H, I) Fixation in Carnoy. J, K, L) Zinc salt fixation (ZSF). All samples were from the same animal and the pictures were taken with $400 x$ magnification; scale bars: $25 \mu \mathrm{m}$. 
- Rinse subsequently in distilled water, tap water, distilled water

- Drying in incubator $30 \mathrm{~min}$ at $60^{\circ} \mathrm{C}$

- Quick immersion in 100\% ethanol, xylene

- Coverslip with ROTI®-HISTOKITT (Carl Roth GmbH + Co. KG, Germany)

Toluidine blue and Alcian blue standard staining procedures. ${ }^{35}$

\section{Tissue shrinkage}

Tissue shrinkage was documented for every step of the embedding procedure. Samples were taken from 6 animals and two localizations (jejunum and colon) for each fixative employed. Tissue was laid mucosal-side up on filter paper (MN 616, circles, $185 \mathrm{~mm}$, Macherey-Nagel GmbH \& Co. KG, Düren, Germany) and directly cut on it. Each sample was placed together with the underlying paper in histology cassettes and put into the fixative. The contour of the tissue was marked on an extra sheet of filter paper (Whatman 10311810, grade 597, circles, 110 $\mathrm{mm}$, Whatman plc, Maidstone, UK) after the fixation, the last ethanol step and the last paraffin step. The contour of the unfixed tissue was derived from the original paper cut. The marked filter papers were scanned; the areas labeled using the image manipulating software GIMP v2.6.11 (GNU Image Manipulation Program, http:/www.gimp.org/team.html) and then measured with GSA Image Analyser v3.8.1 demoversion (GSA, Bansemer \& Scheel GbR, Rostock, Germany). The shrinkage factor for every processing step (fixation, dehydration, paraffin embedding) was calculated as the rate of alteration of the area before $\left(A_{\text {fresh }}\right)$ and $\operatorname{after}\left(A_{x}\right)$ a processing step with $\mathrm{f}_{\text {sample } \mathrm{x}}=\mathrm{A}_{\mathrm{x}} / \mathrm{A}_{\text {fresh }}$. Shrinkage was calculated as the decrease of area in percent after a processing step with $\mathrm{s}_{\text {sample }, \mathrm{x}}=\left(1-\mathrm{f}_{\text {sample }, \mathrm{x}}\right) * 100$.

\section{Average shrinkage factor}

The overall shrinkage factor after paraffin embedding $\mathrm{f}_{\text {sample, paraffin }}=\mathrm{A}_{\text {paraffin }} / \mathrm{A}_{\text {fresh }}$ was used for further calculations. Average shrinkage fac- tors $\mathrm{f}_{\text {fixation, localization }}$ were calculated for each combination of fixation and localization for the normalization to fresh tissue. Because Carnoy s fixative is frequently used for MC quantification, Carnoy shrinkage factors $\mathrm{fc}_{\text {fixa- }}$ tion, localization $=\mathrm{f}_{\text {fixation, localization }} / \mathrm{f}_{\text {carnoy, localization }}$ were additionally used to normalize average shrinkage factors to this fixation.

\section{Quantification of mast cells}

Mast cells were manually counted in 4 different regions: jejunum mucosa, jejunum submucosa, colon mucosa, colon submucosa. For each fixation 3 slides were prepared and an area of at least $1.5 \mathrm{~mm}^{2}$ was evaluated, employing the computer assisted image analysis program NISElements AR (Nikon Instruments Inc., Melville, NY, USA). Concentration of MCs was measured for each sample as the number of MCs per area $\left(\mathrm{MCs}\right.$ per $\left.1 \mathrm{~mm}^{2}\right), \mathrm{MCmm}_{\text {fixed }}^{2}=\mathrm{MC} / \mathrm{A}_{\text {fixed }}$ To compare fixations, measurement values were normalized via the respective shrinkage factor to area of fresh samples with $\mathrm{MCmm}_{\text {fresh }}^{2}=$ $\mathrm{MCmm}_{\text {fixed }}^{2} * \mathrm{f}_{\text {fixation, localization }}$ or to Carnoy fixation with $\mathrm{MCmm}_{\text {Carnoy }}^{2}=\mathrm{MCmm}_{\text {fixed }}^{2} * \mathrm{fc}_{\text {fixation, localization }}$.

\section{Statistics}

All calculations were performed with IBM SPSS 21 (IBM Deutschland GmbH, Ehningen, Germany). Effects on tissue shrinkage were assessed by a linear model with two fixed factors localization (colon and jejunum) and fixation (Carnoy, lead acetate, lead nitrate, Zamboni and ZSF) and with an interaction factor. Effects on MC counts were assessed by a linear mixed model with two fixed factors localization (jejunum mucosa, jejunum submucosa, colon mucosa and colon submucosa) and fixation (Carnoy, lead acetate, lead nitrate, Zamboni and ZSF), an interaction factor and with the factor animal (20 piglets) being a random effect. Post-hoc tests LSD (Least Significant Difference) were applied on fixed factors in case of statistically significant effects.

\section{Results}

\section{Fixation of mast cells, histochem- istry and morphology}

Mast cells could be identified after fixation with ZSF, Carnoy, lead nitrate and lead acetate (Figure 1). The polychromatic methylene blue staining was characterized by its MC specific metachromatic staining in combination with low and uniform orthochromatic staining of the other components of the tissue. Co-stained goblet cells were a feature of both, alcian blue and toluidine blue staining, while the latter also displayed a considerable background staining. Concerning their morphology (Figure 2), porcine intestinal MCs were of oval to elongated shape in the submucosa and were found to have elongated or star shaped cell bodies in the mucosa. Compact, oval to roundish nuclei were visible in cells if not covered by granules. A varying amount of granules was found in the cytoplasm. These were particularly well preserved with the lead fixations that allowed their clear differentiation. In some of the samples fixed with Carnoy or ZSF the granules tended to dissolve and gave a blurry staining result (Figure 2). Also with the lead fixations in some samples veil-like metachromatic signals could be observed in the periphery of MCs (Figure 3A). Zamboni's fixative was not suitable for histochemical detection of MC in the porcine intestine (Figure 3B). In the submucosa of Zamboni-fixed samples some faintly stained MCs could be found but the granular content was not preserved and spread around the cells. Nearly no MCs were detectable in the mucosa.

\section{Tissue shrinkage and resulting shrinkage factor}

After paraffin embedding shrinkage has been found to vary between $19 \%$ (lead acetate - jejunum) and 57\% (ZSF - colon) (Table 2).

Table 2. Shrinkage ratio for the processing steps (fixation, dehydration in ethanol and paraffin embedding) for the different fixatives in the small and large intestine.

\begin{tabular}{|c|c|c|c|c|}
\hline Fixation & Tissue & & sue shrinkage & centage $\pm S D$ \\
\hline & & After fixation & After ethanol & After paraffin embedding \\
\hline Carnoy & Jejunum & $19.46 \pm 9.50$ & $22.74 \pm 11.37$ & $41.33 \pm 6.93$ \\
\hline & Colon & $17.21 \pm 7.48$ & $19.62 \pm 6.44$ & $35.24 \pm 5.14$ \\
\hline Lead acetate & Jejunum & $4.77 \pm 9.15$ & $8.02 \pm 8.93$ & $19.21 \pm 8.14$ \\
\hline & Colon & $13.29 \pm 8.96$ & $15.06 \pm 10.19$ & $25.61 \pm 8.82$ \\
\hline Lead nitrate & Jejunum & $24.52 \pm 8.92$ & $24.02 \pm 9.19$ & $33.21 \pm 7.80$ \\
\hline & Colon & $34.20 \pm 7.81$ & $36.23 \pm 7.45$ & $43.15 \pm 6.84$ \\
\hline Zamboni & Jejunum & $9.07 \pm 7.48$ & $30.39 \pm 6.99$ & $41.13 \pm 5.66$ \\
\hline & Colon & $11.47 \pm 3.23$ & $27.67 \pm 4.49$ & $39.64 \pm 4.77$ \\
\hline Zinc salt fixation & Jejunum & $35.53 \pm 7.35$ & $36.67 \pm 6.84$ & $42.91 \pm 7.28$ \\
\hline & Colon & $48.89 \pm 7.11$ & $50.63 \pm 6.53$ & $56.53 \pm 5.43$ \\
\hline
\end{tabular}




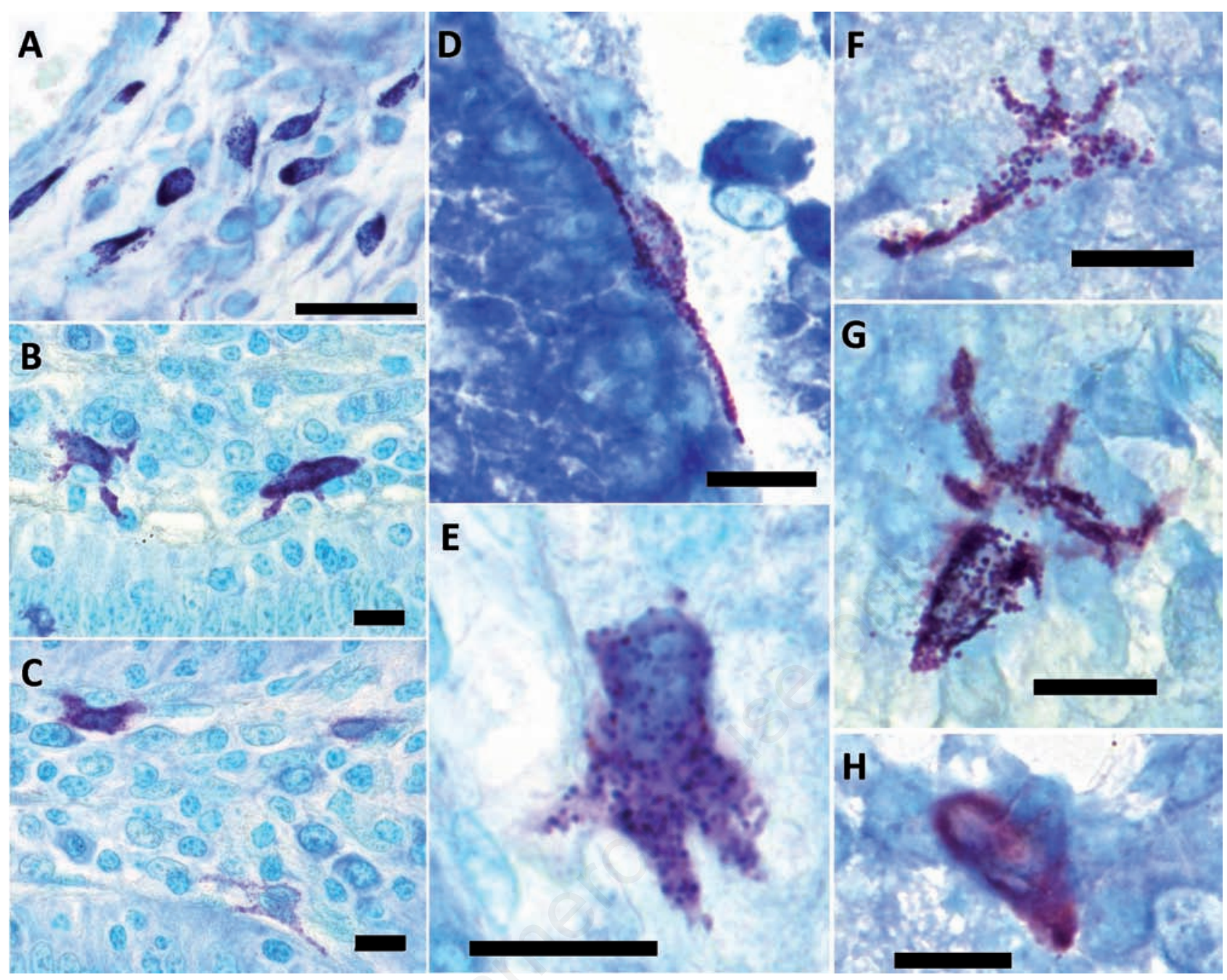

Figure 2. Morphology of porcine intestinal mast cells. Mast cells were of oval to elongated shape in the submucosa (A) and elongated or star shaped in the mucosa (B-G). A varying amount of granules could be found in the cytoplasm of MCs and compact, oval to roundish nuclei were visible in cells if not covered by granules (C). Morphological features and cytoplasmic granules were well preserved with the lead fixations (D-G), while MCs with dissolved granules were frequently found with Carnoy or zinc salt fixation (H). Tissues: colon submucosa (A), colon mucosa $(\mathrm{F}, \mathrm{G})$, jejunum mucosa (B-E, H); Fixation: lead nitrate $(A, D, F, G)$, lead acetate $(B, C, E)$, Carnoy $(H)$; Staining: polychromatic methylene blue; scale bars: A, $25 \mu \mathrm{m}$; B-H, $10 \mu \mathrm{m}$.
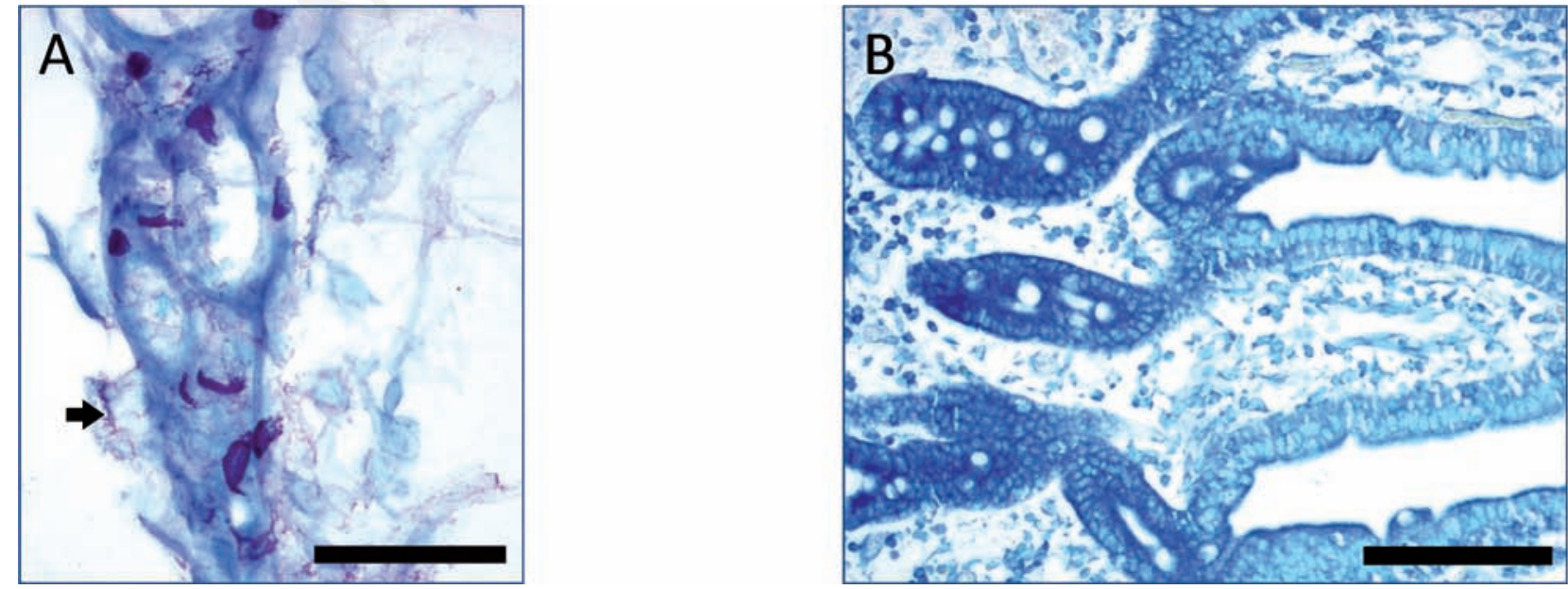

Figure 3. A) Veil-like metachromatic staining signals in the periphery of mast cells of the jejunal submucosa (arrow) fixated with lead nitrate. They could be signs of a degranulation process due to the fact that granular content was otherwise precisely kept in place with that fixative. B) Metachromatic staining of mast cells was absent or faint in samples fixed with Zamboni. Scale bars: A, $50 \mu \mathrm{m} ; \mathrm{B}, 100 \mu \mathrm{m}$. 
The shrinkage ratio calculated after the processing steps varied greatly between the fixations, and even within the same fixation differences between the small and large intestine were found. Resulting shrinkage factors varied significantly between fixations at both localizations (Table 3). Shrinkage factors varied also significantly for the localization after using the same fixation (Figure 4).

\section{Quantification and statistics}

Zamboni was not suitable for counting MCs via metachromatic staining and resulted only in a fractional amount of visible MCs in the submucosa and nearly no MCs in the mucosa compared to the other fixations. Results from tissues fixed this way were therefore eliminated from further analysis. MC counts were adapted via the shrinkage factors (Figure 5). In jejunal mucosal tissue, MC numbers were consistent in all examined fixations after normalization. For other tissue sections however, various significance groups could be found

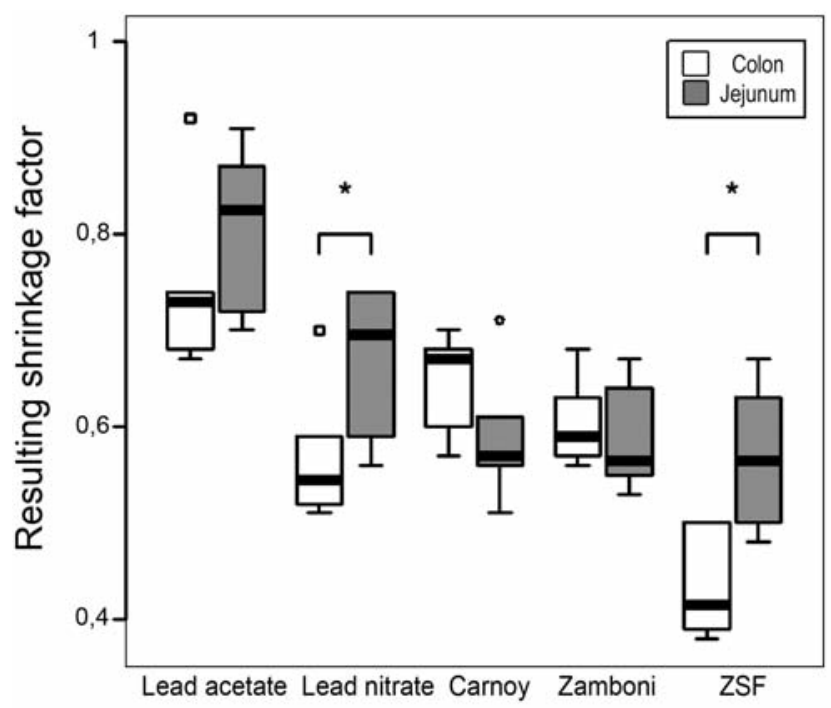

Figure 4. Compar ison of the resulting shrinkage factors for colon and jejunum; the shrinkage varied between localizations after using the same fixation. Carnoy and Zamboni showed no difference whereas shrinkage of colonic tissue was increased compared to jejunal tissue in the heavy metal salt fixations. The effect was significant (indicated by asterisks) for lead nitrate and zinc salt fixation (ZSF).

Fixation

Table 3. Arithmetic mean of resulting shrinkage factors and significance groups for fresh tissue with confidence intervals and for normalization to Carnoy.

\begin{tabular}{|c|c|c|c|c|c|}
\hline & Carnoy & Lead acetate & Lead nitrate & Zamboni & Zinc salt fixation \\
\hline Jejunum & $\begin{array}{c}0.59 \\
(0.53-0.64) \\
1.000 \\
\text { A }\end{array}$ & $\begin{array}{c}0.81 \\
(0.75-0.86) \\
1.377 \\
\text { C }\end{array}$ & $\begin{array}{c}0.67 \\
(0.61-0.72) \\
1.138 \\
\text { B }\end{array}$ & $\begin{array}{c}0.59 \\
(0.53-0.65) \\
1.003 \\
\text { A }\end{array}$ & $\begin{array}{c}0.57 \\
(0.52-0.62) \\
0.973 \\
\text { A }\end{array}$ \\
\hline Colon & $\begin{array}{c}0.65 \\
(0.59-0.70) \\
1.000 \\
\text { C }\end{array}$ & $\begin{array}{c}0.74 \\
(0.69-0.80) \\
1.149 \\
\text { D }\end{array}$ & $\begin{array}{c}0.57 \\
(0.51-0.62) \\
0.878 \\
B\end{array}$ & $\begin{array}{c}0.60 \\
(0.55-0.66) \\
0.932 \\
B, C\end{array}$ & $\begin{array}{c}0.44 \\
(0.38-0.49) \\
0.671 \\
\mathrm{~A}\end{array}$ \\
\hline
\end{tabular}

SG, significance groups. A, B, C, D, different letters indicate for significant differences among fixations; same group for two fixation means there is no significant difference between them.

Table 4. Number of mast cells and differences between original and normalized data. Mast cells numbers with confidence intervals in this table were normalized to Carnoy fixation.

\begin{tabular}{|c|c|c|c|c|}
\hline & Carnoy & Lead acetate & Lead nitrate & Zinc salt fixation \\
\hline Jejunum mucosa & $\begin{array}{c}217 \\
(195-240)\end{array}$ & $\begin{array}{c}238 \\
(217-258)\end{array}$ & $\begin{array}{c}239 \\
(219-260)\end{array}$ & $\begin{array}{c}236 \\
(219-253)\end{array}$ \\
\hline SG Carnoy & A & $\mathrm{A}$ & A & A \\
\hline SG original & B & A & $\mathrm{B}$ & $\mathrm{C}$ \\
\hline Jejunum submucosa & $\begin{array}{c}193 \\
(171-215)\end{array}$ & $\begin{array}{c}229 \\
(207-251)\end{array}$ & $\begin{array}{c}190 \\
(170-211)\end{array}$ & $\begin{array}{c}184 \\
(167-202)\end{array}$ \\
\hline SG Carnoy & A & B & $\mathrm{A}$ & $\mathrm{A}$ \\
\hline SG original & A & $\mathrm{A}$ & $\mathrm{A}$ & $\mathrm{A}$ \\
\hline Colon mucosa & $\begin{array}{c}173 \\
(151-195)\end{array}$ & $\begin{array}{c}167 \\
(147-188)\end{array}$ & $\begin{array}{c}149 \\
(129-170)\end{array}$ & $\begin{array}{c}129 \\
(112-147)\end{array}$ \\
\hline SG Carnoy & B & B & A, B & A \\
\hline SG original & $\mathrm{A}, \mathrm{B}$ & $\mathrm{A}$ & A, B & $\mathrm{B}$ \\
\hline Colon submucosa & $\begin{array}{c}170 \\
(147-192)\end{array}$ & $\begin{array}{c}160 \\
(139-180)\end{array}$ & $\begin{array}{c}138 \\
(118-159)\end{array}$ & $\begin{array}{c}105 \\
(87-122)\end{array}$ \\
\hline SG Carnoy & C & $\mathrm{B}, \mathrm{C}$ & B & A \\
\hline SG original & B & A & $A, B$ & A, B \\
\hline
\end{tabular}

SG, significance groups. SG original, distribution of groups for the original measurement without normalization. A, B, C, D, different letters indicate for significant differences among fixations; same group for two fixation means there is no significant difference between them. 
(Table 4). If no normalization factor was applied, the significance groups showed a different distribution pattern (Table 4).

\section{Discussion}

The aim of this study was to evaluate tissue fixation and staining methods for subsequent identification of MCs in the porcine small and large intestine. Tissues were fixed in Carnoy, lead acetate, lead nitrate, Zamboni and ZSF and stained subsequently with either polychromatic methylene blue, alcian blue or toluidine blue. Results showed that Zamboni fixation was not suitable for histochemical visualization of MCs in the porcine intestine. All other tested fixatives were suitable for histochemical visualization of porcine intestinal MCs, however, MC counts in the submucosa of the small intestine and in the mucosa and submucosa of the large intestine were heterogeneous. In order to compare MC counting results of the different fixation methods, tissue shrinkage was taken into account. The highest tissue shrinkage was found after fixation with ZSF in the large intestine, the lowest one in the small intestine after lead acetate fixation.

\section{Fixations}

Staining properties of MCs are influenced by the method of fixation. Our results showed that all fixatives tested were suitable for histochemical visualization of porcine MCs with the exception of Zamboni's fixative that did not preserve metachromatic staining properties of MCs, neither in the porcine intestinal mucosa nor submucosa. In contrast to our results, Zamboni was reported to preserve the granules of MCs well and distinctly in the rat, as shown by both light- and electron-microscopic IHC. ${ }^{28}$ This highlights the species-specific properties of MCs and emphasizes the influence of fixation procedures on MC detection. An earlier study ${ }^{41}$ describing MC staining in the camel also underlined the fact that data regarding MC heterogeneity from other species, obtained by different fixation methods, are not comparable. A reason for the species-specific reaction of MCs to specific fixatives is probably the different amount and combination of chemical constituents within their cytoplasmic granules. ${ }^{42}$

Jirge et al. studied MCs histochemically in relation to various fixation and staining procedures in the pig and other species. Similar to the results of our study, they described that counts of MCs in the pig were higher after heavy metal fixation than after fixation with aldehydes, but vice-versa in other tested species. $^{43}$

Like the aldehyde and heavy metal fixations, Carnoy is also frequently used for the exami-

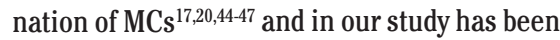
found to show satisfactory results for the evaluation of porcine MCs. This fixative, which contains ethanol, chloroform and glacial acetic acid, is suitable for the histochemical examination of proteins and carbohydrates and has been used in many conventional and special staining techniques. ${ }^{49}$ Granules of MCs in special locations (e.g., mucosal MCs) in many species are water soluble and therefore require alcoholic fixation (like Carnoy) for preservation. ${ }^{49}$ Likewise, lead acetate and lead nitrate both contain alcohol plus a heavy metal salt. Parwaresch and Lennert found that the complete water resistance of basophilic granules manifests their sufficient fixation and that for example basic lead acetate proved to be a good fixative for that purpose.$^{50}$ The mechanism behind this is likely to involve the precipitation of mucopolysaccharides or associated proteins from the MC granules. ${ }^{7}$

Focus has turned recently to a certain nonaldehyde based fixative, i.e. ZSF. It combines good morphological with good antigen preservation including intracellular and surface epitopes and for example allows simultaneous

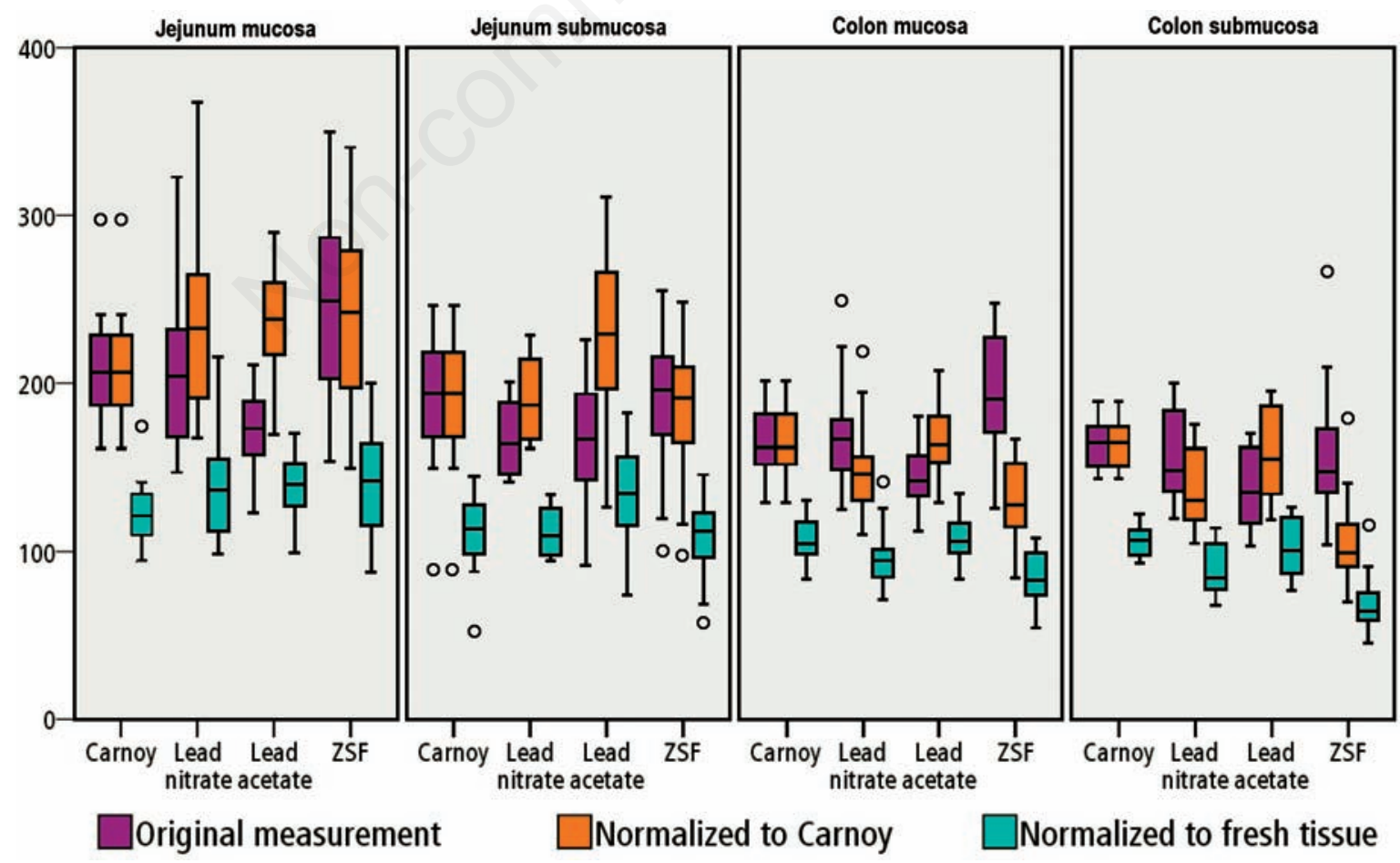

Figure 5. Mast cells per $\mathrm{mm}^{2}$. Original mast cell counting results compared with results adapted via the shrinkage factors individually plotted for each tissue section. 
analysis of DNA content and synthesis along with the analysis of cells via flow cytometry. ${ }^{29,51-53}$ Therefore we also included zinc salt as a new fixation procedure for MCs. For the first time our study revealed that ZSF, also a heavy metal fixative, preserves metachromatic staining properties of porcine MCs. Barranco et al. compared three different fixatives, namely $10 \%$ buffered formalin, Bouin and ZSF, and found only the latter one to be an excellent fixative for IHC in apoptosis assays for porcine tissues. ${ }^{54}$ ZSF was also used to detect immune system cells in mice ${ }^{29}$ and humans ${ }^{55}$ with good results. Moreover, a considerable advantage of ZSF compared to the other heavy metal fixatives as well as Carnoy fixative is its reduced toxicity.

\section{Histochemistry and morphology}

Mast cells were first described by Paul Ehrlich in his 1878 doctoral thesis, on the basis of their large granules and unique socalled metachromatic staining. ${ }^{56}$

As the MC-specific granules contain the glycosaminoglycans heparin and/or chondroitin sulfate, i.e. sulphated mucopolysaccharides which are responsible for their metachromatic labeling, $, 10,57$ it is important to use a fixative which preserves these components. In our study, the metachromatic dyes toluidine blue and polychromatic methylene blue as well as the orthochromatic alcian blue were tested for MC staining. Alcian blue co-stained intestinal goblet cells, which made a prima facie identification of MCs difficult within our target sample tissue. Toluidine blue likewise stained goblet cells and produced a considerable background staining. Polychromatic methylene blue staining was superior to alcian blue and toluidine blue due to its clear MC-specific metachromatic staining in combination with low and uniform orthochromatic staining of the remaining compounds of the tissue. This result from our study is also supported in earlier evaluations of different histologic stains for MCs in primates, guinea pigs and dogs. ${ }^{58,59}$ Nevertheless, the variable, presumably tissuespecific staining behavior of MCs has generally to be taken into account even when comparing results from one species, as for example $\mathrm{Xu}$ et al. found a significant difference when comparing porcine $\mathrm{MC}$ counting results using the same fixation but different stainings. They compared alcian blue and toluidine blue and found the first one to stain more MCs, ${ }^{17}$ which was also confirmed by Vodenicharov et al. for the porcine ureter.$^{60}$ In general, intestinal MCs have a lower affinity to thiazine dyes like toluidine blue and a higher affinity for basic copper phtalocyanine dyes like alcian blue. ${ }^{8}$

It has to be kept in mind that, similar to MCs, basophils also contain prominent metachromatic cytoplasmic granules, ${ }^{61}$ but it was demonstrated that cells of the basophilic cell line contribute to no great extent to the number of metachromatic cells in normal intestinal mucosa. ${ }^{62}$ By counting granulocytes and $\mathrm{MC}$ of the intestinal mucosa of probiotictreated and control piglets, Duncker et al. found no basophils within the mucosal layers in untreated animals. ${ }^{24}$ Therefore, stainingconditioned erroneous inclusion of basophils in either digital analysis system assisted or (as in our study) manual MC counts are probably not of great importance when assessing healthy tissue. Counting of MCs asks for a reliable staining and identification. Since the times of Ehrlich the majority of identification methods for MCs depend on the presence of components of secretory granules which disappear upon degranulation. As Buckley and Walls reviewed, in most cases MC degranulation may be partial rather than total, but there may be particular difficulties in detecting MCs where a substantial degree of degranulation has occurred. The potential for such phantom MCs, which fail to stain with dyes is well established. ${ }^{16}$ Therefore, we cannot exclude that also with the carefully adapted and evaluated procedures employed within our study, the recorded MC number may have been underestimated.

Mast cell morphology was found to be in accordance with descriptions from the literature. ${ }^{17,49,60,63,64}$ An interesting finding were the star shaped MCs which resided in the mucosa of both jejunum and colon and were not mentioned in the description of porcine MCs by Xu et al. ${ }^{17}$ The star shaped MCs and also the bigger spindle shaped MCs with elongated processes represent presumably an activated or special type of MC whereas the smaller round cells represent a resting state. ${ }^{65-67}$

\section{Shrinkage}

Tissue shrinkage is an important factor with a crucial impact when comparing results gained from differently processed samples. ${ }^{68}$ In order to allow comparison of MC counting results published by other authors and from own data, the respective study-immanent shrinkage factor needs to be determined and quantification results have to be adjusted accordingly.

In our study we found that shrinkage after paraffin embedding varied between $19 \%$ and $57 \%$, a fact which obviously had great impact on the MC quantification results. The uncorrected data for jejunum mucosa implied differences in counting results between the different fixatives employed, whereas after correction these differences were no longer present. The shrinkage ratios after the different processing steps (fixation, alcohol dehydration and paraffin embedding) varied; i.e., after lead acetate fixation of the jejunum shrinkage ratio was $4.77 \pm 9.15 \%, \quad$ e.g. in contrast to $48.89 \pm 7.11 \%$ after ZSF fixation of colonic tissue. In addition to the variations of tissue shrinkage employing the different fixations, even using the same fixation caused shrinkage-differences between tissue from small and large intestine. This demanded the use of different factors for each single fixation and intestinal localization.

Clearly there are limits to the method applied in our study, in which only the areashrinkage of the whole tissue was measured. Earlier studies on effects of histological processing in cancer samples ${ }^{69}$ reported that variables like whole-mount $v s$ quadrant sections, thickness of tissue slices, length of time of the alcohol dehydration steps, and varying temperature of the flotation bath did not have a significant influence on tissue shrinkage. Within our study we observed that mucosa and submucosa seemed to shrink to a different extent and not evenly in all samples. Therefore intraorgan specific differences between mucosa and submucosa can be assumed, potentially influencing the results. Architecturally, the mucosa is a relatively tough compartment in contrast to the underlying submucosa which is designed to act as a shifting layer between the tunica mucosa and the tunica muscularis, enabling them to move against each other, ${ }^{70}$ possibly resulting in varying shrinkage potential for this compartment. In a study on porcine stomach submucosa an individual variation in a range from 3 to $70 \%$ of the observed morphological parameter was detected. ${ }^{71}$ Their and our results indicate that in future studies on (mast) cell counting individual shrinkage factors for individual tissue layers may need to be determined.

\section{Mast cell quantification results of porcine intestinal tissue}

Strobel et al. emphasized that differences in fixation and staining techniques may explain the contradictory results in the published reports on the number of human MCs in the gastrointestinal mucosa in health and disease. Their results show a critical influence of the fixative on the number of MCs identified after staining. These authors discussed the tissue shrinkage, but decided that it would not bias their results. ${ }^{15}$ When comparing available data concerning the pig from studies employing the same fixatives as tested within our study, our results from $\mathrm{MC}$ counting were generally in agreement with the results of other authors. ${ }^{11,12,17}$

Besides the fixation, a limiting factor for the comparison of results of different studies is the variety of used material and methods. Moreover, age ${ }^{72}$ and breeding conditions may also influence the number of MCs. The inci- 
dence of (sub-)clinical conditions such as infection with parasites etc., has a well-known impact on MC numbers. ${ }^{11,73-75}$ Therefore, comparison of data from studies using different tissue processing procedures should be approached with caution, because without a corrective tissue shrinkage factor these data may not objectively be transferable.

\section{Conclusions}

Tissue shrinkage is an important factor with a crucial impact when comparing results gained from samples processed with different fixatives. Thus, in order to allow comparison of data, the respective study-immanent shrinkage factor needs to be determined and quantification results have to be adjusted accordingly. Polychromatic methylene blue is suitable for the detection of porcine intestinal MCs when their granular content is properly fixed. ZSF - a new fixative recently employed for its excellent antigen-preservation properties used in IHC - is suitable for detecting MCs via histochemical methods. ZSF may therefore be the fixative of choice for studies planning to characterize MCs by both histochemical and immunohistochemical methods that hitherto demanded the combination of different fixation procedures for optimal results.

\section{References}

1. Smith F, Clark JE, Overman BL, Tozel CC, Huang JH, Rivier JEF, et al. Early weaning stress impairs development of mucosal barrier function in the porcine intestine. Am J Physiol Gastrointest Liver Physiol 2010;298: G352-63.

2. Abraham SN, St. John AL. Mast cell-orchestrated immunity to pathogens. Nat Rev Immunol 2010;10:440-52.

3. Moon TC, St Laurent CD, Morris KE, Marcet C, Yoshimura T, Sekar Y, et al. Advances in mast cell biology: new understanding of heterogeneity and function. Mucosal Immunol 2009;3:111-28.

4. Oksaharju A, Kankainen M, Kekkonen RA, Lindstedt KA, Kovanen PT, Korpela R, et al. Probiotic Lactobacillus rhamnosus downregulates FCER1 and HRH4 expression in human mast cells. World J Gastroenterol 2011;17:750-9.

5. Cho JH, Zhao PY, Kim IH. Probiotics as a dietary additive for pigs: a review. J Anim Vet Adv 2011;10:2127-34.

6. Sharbati S, Friedländer M, Sharbati J, Hoeke L, Chen W, Keller A, et al. Deciphering the porcine intestinal microRNA transcriptome.
BMC Genomics 2010;11:275.

7. Enerbäck L. Mast cells in rat gastrointestinal mucosa. I. Effects of fixation. Acta Pathol Microbiol Scand 1966;66:289-302.

8. Enerbäck L. Mast cells in rat gastrointestinal mucosa. 2. Dye-binding and metachromatic properties. Acta Pathol Microbiol Scand 1966;66:303-12.

9. Enerbäck L. Mucosal mast cells in the rat and in man. Int Arch Allergy Appl Immunol 1987;82:249-55.

10. Enerbäck L. The gut mucosal mast cell, pp. 222-32. In: L. Edebo, 0.I. Stendahl, L. Enerbäck (eds.) Endocytosis and Exocytosis in Host Defence. Karger, Basel, 1981.

11. Pabst R, Beil W. Mast cell heterogeneity in the small intestine of normal, gnotobiotic and parasitized pigs. Int Arch Allergy Appl Immunol 1989;88:363-6.

12. Beil WJ, McEuen AR, Schulz M, Wefelmeyer U, Kraml G, Walls AF, et al. Selective alterations in mast cell subsets and eosinophil infiltration in two complementary types of intestinal inflammation: ascariasis and Crohn's disease. Pathobiology 2002;70:303-13.

13. Martelli F, Ghinassi B, Lorenzini R, Vannucchi AM, Rana RA, Nishikawa M, et al. Thrombopoietin inhibits murine mast cell differentiation. Stem Cells 2008;26: 912-9.

14. Martínez J, Martínez V, Grau-Roma L, López J, Segalés J. Multiple cutaneous mast cell tumors in a pig. J Vet Diagn Invest 2011;23: 1222-5.

15. Strobel S, Miller HR, Ferguson A. Human intestinal mucosal mast cells: evaluation of fixation and staining techniques. J Clin Pathol 1981;34:851-8.

16. Buckley M, Walls AF. Identification of mast cells and mast cell subpopulations, pp. 28597. In: M.G. Jones, P. Lympany (eds.) Allergy Methods and Protocols. Humana Press, Totowa, NJ, USA, 2008.

17. Xu L, Carr M, Bland A, Hall G. Histochemistry and morphology of porcine mast cells. Histochem J 1993;25:516-22.

18. Beil WJ, Schulz M, McEuen AR, Buckley MG, Walls AF. Number, fixation properties, dyebinding and protease expression of duodenal mast cells: comparisons between healthy subjects and patients with gastritis or Crohn's disease. Histochem J 1997; 29:75973.

19. Kube P, Audigé L, Küther K, Welle M. Distribution, density and heterogeneity of canine mast cells and influence of fixation techniques. Histochem Cell Biol 1998;110: 129-35.

20. Marshall JS, Ford GP, Bell EB. Formalin sensitivity and differential staining of mast cells in human dermis. Br J Dermatol 1987;17:2936.

21. Walls AF, Jones DB, Williams JH, Church MK, Holgate ST. Immunohistochemical identifi- cation of mast cells in formaldehyde fixed tissue using monoclonal antibodies specific for tryptase. J Pathol 1990;162:119-26.

22. Wingren U, Enerbäck L. Mucosal mast cells of the rat intestine: a re-evaluation of fixation and staining properties, with special reference to protein blocking and solubility of the granular glycosaminoglycan. Histochem J 1983;15:571-82.

23. Che C, Pang X, Hua X, Zhang B, Shen J, Zhu $\mathrm{J}$, et al. Effects of human fecal flora on intestinal morphology and mucosal immunity in human flora associated piglet. Scand J Immunol 2009;69:223-33.

24. Duncker SC, Lorentz A, Schroeder B, Breves G, Bischoff SC. Effect of orally administered probiotic E. coli strain Nissle 1917 on intestinal mucosal immune cells of healthy young pigs. Vet Immunol Immunopathol 2006;111: 239-50.

25. Shetye JD, Scheynius A, Mellstedt HT, Biberfeld P. Retrieval of leukocyte antigens in paraffin-embedded rat tissues. J Histochem Cytochem 1996;44:767-76.

26. Konttinen YT, Bergroth V, Käyhkö K, Reitamo S. Human ferritin: effects of antigen source and fixation on leucocyte staining by immunoperoxidase technique. Histochemistry 1982;75:585-9.

27. Kanbe N, Kurosawa M, Miyachi Y, Kanbe M, Kempuraj D, Tachimoto H, et al. Carnoy's fixative reduces the number of chymase-positive cells in immunocytochemical staining of cord-blood-derived human cultured mast cells. Allergy 1998;53:981-5.

28. Hosoi K, Matsuura S, Tsumura K, Wei W, Parvin MN, Tada $\mathrm{J}$, et al. Expression of kininogens in the connective tissue-type mast cells of the rat. Immunology 2000;101: 531-40.

29. Hicks DJ, Johnson L, Mitchell SM, Gough J, Cooley WA, La Ragione RM, et al. Evaluation of zinc salt based fixatives for preserving antigenic determinants for immunohistochemical demonstration of murine immune system cell markers. Biotech Histochem 2006;81:23-30.

30. Breugelmans S, Van den Broeck W, Demeyere K, Meyer E, Simoens P. Immunoassay of lymphocyte subsets in ovine palatine tonsils. Acta Histochem 2011; 113:416-22.

31. Romeis B. [Mikroskopische Technik.] [Book in German]17th ed. P. Böck P (ed.) München, Wien, Baltimore: Urban und Schwarzenberg; 1989.

32. Carnoy JB, Lebrun H. [La vésicule germinative et les globules polaires chez les batraciens]. [Book in French]. Joseph van In, 1899.

33. Mota I, Beraldo WT, Ferri AG, Junqueira LCU. Intracellular distribution of histamine. Nature 1954;174:698. 
34. Mota I, Vugman I. Effects of anaphylactic shock and compound 48/80 on the mast cells of the guinea pig lung. Nature 1956;177:427-9.

35. Mulisch M, Welsch U. Romeis. [Mikroskopische Technik]. [Book in German]. 18th ed. Spektrum Akademischer Verlag, Heidelberg, 2010.

36. Lillie RD. Histopathologic technic and practical histochemistry. McGraw-Hill, New York, 1954.

37. Zamboni I, De Marino C. Buffered picric acid-formaldehyde: a new rapid fixative for electron microscopy. J Cell Biol 1967; 148A.

38. Stefanini M, Martino CD, Zamboni L. Fixation of ejaculated spermatozoa for electron microscopy. Nature 1967;216:173-4.

39. González L, Anderson I, Deane D, Summers C, Buxton D. Detection of immune system cells in paraffin wax-embedded ovine tissues. J Comp Pathol 2001;125:41-7.

40. Romeis B. [Mikroskopische Technik]. [Book in German] 16th ed. München, Wien: R. Oldenbourg Verlag; 1968.

41. Al-Zghoul MB, Al-Rukibat RK, Alghadi M, Caceci T, Bani Ismail Z. Distribution and density of mast cells in camel small intestine and influence of fixation techniques. Eur $\mathrm{J}$ Histochem 2008;52:237-41.

42. Rocha JS, Chiarini-Garcia H. Mast cell heterogeneity between two different species of Hoplias sp. (Characiformes: Erythrinidae): Response to fixatives, anatomical distribution, histochemical contents and ultrastructural features. Fish Shellfish Immunol 2007;22:218-29.

43. Jirge SK, Catalano RA, Lillie RD. Some histochemical reactions of mast cells of gerbils, hogs, armadillos and cats. Histochemistry 1974;40:129-35.

44. Markey AC, Churchill LJ, MacDonald DM. Human cutaneous mast cells - a study of fixative and staining reactions in normal skin. Br J Dermatol 1989;120:625-31.

45. Küther K, Audigé L, Kube P, Welle M. Bovine mast cells: distribution, density, heterogeneity, and influence of fixation techniques. Cell Tissue Res 1998;293:111-9.

46. Valchanov KP, Proctor GB, Hartley RH, Paterson KL, Shori DK. Enzyme histochemistry of rat mast cell tryptase. Histochem J 1998;30:97-103.

47. Pickles KJ, Mair JA, Lopez-Villalobos N, Shaw DJ, Scott I, Pomroy W. Large intestinal mast cell count and proteinase expression is associated with larval burden in cyathostomin-infected horses. Equine Vet J 2010;42: 652-7.

48. Puchtler H, Sweat Waldrop F, Conner HM, Terry MS. Carnoy fixation: practical and theoretical considerations. Histochemie 1968; 16:361-71.

49. Yong LCJ. The mast cell: origin, morphology, distribution, and function. Exp Toxicol
Pathol 1997;49:409-24.

50. Parwaresch MR, Lennert K. [Löslichkeit und Fixierungsmöglichkeiten der Blutbasophilen-Granula des Menschen]. [Article in German]. Cell Tissue Res 1967;83:279-87.

51. Jensen UB, Owens DM, Pedersen S, Christensen R. Zinc fixation preserves flow cytometry scatter and fluorescence parameters and allows simultaneous analysis of DNA content and synthesis, and intracellular and surface epitopes. Cytometry A 2010;77:798-804.

52. Hadler-0lsen E, Kanapathippillai P, Berg E, Svineng G, Winberg J-0, Uhlin-Hansen L. Gelatin in situ zymography on fixed, paraffin-embedded tissue: zinc and ethanol fixation preserve enzyme activity. J Histochem Cytochem 2010;58:29-39.

53. Wester K, Asplund A, Bäckvall H, Micke P, Derveniece A, Hartmane I, et al. Zinc-based fixative improves preservation of genomic DNA and proteins in histoprocessing of human tissues. Lab Invest 2003;83:889-99.

54. Barranco I, Gómez-Laguna J, RodríguezGómez IM, Salguero FJ, Pallarés FJ, Bernabé A, et al. Immunohistochemical detection of extrinsic and intrinsic mediators of apoptosis in porcine paraffin-embedded tissues. Vet Immunol Immunopathol 2011;139:210-6.

55. Beckstead JH. A simple technique for preservation of fixation-sensitive antigens in paraffin-embedded tissues. J Histochem Cytochem 1994;42:1127-34.

56. Beaven MA. Our perception of the mast cell from Paul Ehrlich to now. Eur J Immunol 2009;39:11-25.

57. Jaques LB. The mast cells in the light of new knowledge of heparin and sulfated mucopolysaccharides. Gen Pharmacol 1975; 6:235-45.

58. Graham JS, Bryant MA, Kirkpatrick LJ, Moltrup DL. Staining mast cells for morphometric evaluation on an image analysis system. Biotech Histochem 1994;69:121-6.

59. Kube P. [Canine Mastzellen: Verteilung, Dichte und Heterogenität sowie Einfluss zweier Fixationstechniken - Theorie von Reaktions-Migrations-Systemen.] [Thesis in German]. Freie Universität Berlin; 2000.

60. Vodenicharov A, Leiser R, Gulubova M, Vlaykova T. Morphological and immunocytochemical investigations on mast cells in porcine ureter. Anat Histol Embryol 2005;34: 343-9.

61. Stone KD, Prussin C, Metcalfe DD. IgE, mast cells, basophils, and eosinophils. J Allergy Clin Immunol 2010;125:73-80.

62. Aldenborg F, Enerbäck L. The immunohistochemical demonstration of chymase and tryptase in human intestinal mast cells. Histochem J 1994;26:587-96.

63. Drake-Lee AB, Price J. A review of the morphology of human nasal mast cells as studied by light and electron microscopy. Rhinology 1992;30:229-39.

64. Jones CJP, Kirkpatrick CJ, Stoddart RW. An ultrastructural study of the morphology and lectin-binding properties of human mast cell granules. Histochem J 1988;20:433-42.

65. Frossi B, Gri G, Tripodo C, Pucillo C. Exploring a regulatory role for mast cells: 'MCregs'? Trends Immunol 2010;31: 97-102.

66. Ahuja N, Paul M, Bakshi Y, Singh H. Ultrastructural and light microscopic study to determine the potential role of mast cells in pathogenesis of oral lichen planus. Internet Journal of Pathology 2011;12:e1.

67. Marchini-Alves CMM, Nicoletti LM, Mazucato VM, Souza LB de, Hitomi T, Alves $\mathrm{C}$ de $\mathrm{P}$, et al. Phospholipase D2: a pivotal player modulating RBL-2H3 mast cell structure. J Histochem Cytochem 2012;60: 386-96.

68. Iwadare T, Mori $\mathrm{H}$, Ishiguro $\mathrm{K}$, Takeishi $\mathrm{M}$. Dimensional changes of tissues in the course of processing. J Microsc 1984;136: 323-7.

69. Schned AR, Wheeler KJ, Hodorowski CA, Heaney JA, Ernstoff MS, Amdur RJ, et al. Tissue-shrinkage correction factor in the calculation of prostate cancer volume. Am J Surg Pathol 1996;20:1501-6.

70. Bucher 0, Wartenberg H. [Cytologie, Histologie und mikroskopische Anatomie des Menschen. 12. Vollständ. b-überarb.] [Book in German]. Hans Huber, Bern Göttingen Toronto Seattle, 1997.

71. Park S, Chun HJ, Kwon YD, Keum B, Seo YS, Kim YS, et al. Stretching causes extensive changes of gastric submucosa: is it acceptable to define $500 \mu \mathrm{m}$ as the safe margin? Gut Liver 2008;2:199-204.

72. Castillo Pena GA, Garrido Farina GI, Ochoa Uribe G, Garcia Tovar CG, Cruz Sanchez TA. Distribution of mast cells in the respiratory tract of the pig at three stages of development. J Anim Vet Adv 2009;8:2241-6.

73. Birck MM, Pors S, Johansen MV, Iburg T. Distribution of mast cells in relation to Schistosoma japonicum induced lesions in pigs. Southeast Asian J Trop Med Public Health 2006;37:630-40.

74. Kringel H, Iburg T, Dawson H, Aasted B, Roepstorff A. A time course study of immunological responses in Trichuris suis infected pigs demonstrates induction of a local type 2 response associated with worm burden. Int J Parasitol 2006;36:915-24.

75. Cruz Sanchez TA, Martinez Robles SS, Garrido Farina G, Tortora Perez J, Mendoza Elvira S, Ciprian Carrasco A, et al. In situ analysis of CD4, CD8 and mast cells in lung of Mycoplasma hyopneumoniae experimentally infected pigs. Anim Vet Adv 2008;7:752-8. 